\title{
Mesenteric Vein Thrombosis Due to Protein S Deficiency in a Girl
}

\author{
Protein S Eksikliğine Bağlı Mezenter Ven Trombozu Gelișen Kız Hasta
}

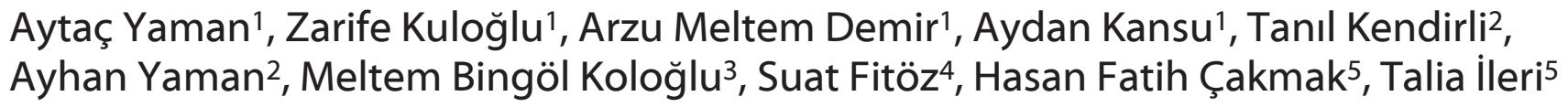

1. Department of Pediatric Gastroenterology, Ankara University,
Faculty of Medicine Ankara, Turkey.
2 Department of Pediatric Intensive Care, Ankara University,
Faculty of Medicine, Ankara, Turkey.
3 Department of Pediatric Surgery, Ankara University, Faculty of
Medicine, Ankara, Turkey.
4 Department of Pediatric Radiology, Ankara University, Faculty of
Medicine, Ankara, Turkey.
5 Department of Pediatric Hematology, Ankara University, Faculty
of Medicine, Ankara, Turkey
Received: $12.06 .2014 \bullet$ Accepted: 01.07.2014

Corresponding Author

Aytaç Yaman M.D.

Telephone (mobile) +90 (537) 5424169

Telephone (Work): +90 (312) 5956556

Fax: +90 (312) 3191440

e-mail: aytacyaman@gmail.com

Adress: Güzeltepe Mah. Halit Ziya Sk. No: 10/6 Çankaya-

Ankara TURKEY

Mesenteric venous thrombosis (MVT) is a very rare condition in children, and may cause bowel infarction and gangrene. It may be caused by congenital or acquired factors, including protein $\mathrm{S}$ deficiency; a very rare genetic disorder. Here we report a case of MVT in a girl with protein S deficiency. The patient developed splenic necrosis and massive small bowel infarction sparing the colon. Contrast enhanced computed tomography led to prompt diagnosis of small bowel and splenic necrosis. The patient was treated successfully by resection of the necrotic bowel and anticoagulant therapy.

Key Words: Mesenteric Venous Thrombosis, Protein S Deficiency

Mezenterik ven trombozu (MVT) çocuklarda seyrek görülen bir durum olup barsak nekrozuna neden olabilmektedir. Mezenterik ven trombozu konjenital ve edinsel faktörlerle ilișkili olup Protein S eksikliği de bunların arasında yer alır. Burada protein S eksikliği olan bir kız çocuğunda görülen MVT olgusu sunulmaktadır. Kontrastlı bilgisayarlı tomografi incelemesi ile hastada dalak nekrozu ve geniș alanlarda kolonun korunduğu barsak nekrozu gözlenmiștir. Barsak rezeksiyonu ve antikoagulan tedavi sonrasında hasta bașarıyla tedavi edilmiștir.

Anahtar Sözcükler: Mezenter Ven Trombozu, Protein S Eksikliği

Mesenteric venous thrombosis (MVT) is an uncommon condition in children which is associated with intestinal infarction and a poor outcome [1]. The most common etiologies include prothrombotic states such as congenital coagulation disorders, paraneoplastic syndromes, intraabdominal inflammatory conditions, the postoperative state, cirrhosis and portal hypertension [2]. Protein S deficiency (PSD) is an inherited or acquired disorder associated with an increased risk of thrombosis. However, it is a rare cause of MVT. To our knowledge, MVT has been reported in only one child with PSD [3]. Herein, we report a girl with PSD who developed MVT.

\section{CASE REPORT}

An eight-year-old girl was refererd to our center because of intensive, projectile hemorrhagic vomiting, generalised tonic clonic seizure and a distended, rigid abdomen. She had nonhemorrhagic vomiting intermittently the week before. At 3.5 years she had a generalized tonic clonic seizure caused by an intracranial hemorrhage. Screening tests for coagulopathy showed low free Protein S levels (23\%). Tests for F V Leiden thrombophilia, prothrombin 20210A mutation and methylene tetrahydrofolate deficiency were negative. Genetic deficiency of protein $\mathrm{S}$ was considered to be highly probable as her mother and one of her sisters also had low levels of protein S. Antithrombotic therapy was not initiated at that time due to intracranial hemorrhagic lesion. She received valproic acid for 2 years after the event.

On admission, she had palor and confusion. She was tachycardiac (140/min), tachypneic (44/ $\mathrm{min})$ and hypertensive (162/102 $\mathrm{mmHg})$. Her abdomen was tender and rigid with marked distention. Laboratory investigations showed; hemoglobin 
$3.7 \mathrm{~g} / \mathrm{dl}$; hematocrit $14 \%$; thrombocyte count $110000 / \mathrm{mm} 3$; white blood cell count $29600 / \mathrm{mm}^{3}$, (66.5 \% neutrophils, $23.1 \%$ lymphocytes $10 \%$ monocytes), Creactive protein $200.6 \mathrm{mg} / \mathrm{L}$. The prothrombin time was $159 \mathrm{sec}$, partial thromboplastin time was longer than measuring limit, international normalized ratio (INR): 12.26 and d-dimer: $5400 \mu \mathrm{g} / \mathrm{L}$. Her blood chemistry revealed increased creatinine levels of $1.65 \mathrm{mg} / \mathrm{dl}$, hyponatremia $(132 \mathrm{mEq} / \mathrm{L})$, hyperkalemia (6 $\mathrm{mEq} / \mathrm{L})$, hyperphosphatemia (8 $\mathrm{mg} / \mathrm{dl})$, hyperuricemia (12.3 $\mathrm{mg} / \mathrm{dl})$, hypertransaminasemia (ALT: $96 \mathrm{U} /$ L, AST: 135 U/L). She was promptly transfused with packed red blood cells and fresh frozen plasma. Cranial computed tomographic (CT) scan showed no abnormalities. Abdominal CT with contrast enhancement showed complete thrombosis of the superior mesenteric vein that had spread to extrahepatic portal vein and the splenic vein, and consequent ischemia of the small intestine and massive splenic necrosis (Fig.1 and Fig. 2). Subsequently, she underwent resection of the necrotic small bowel from the treitz ligament to $20 \mathrm{~cm}$ proximal to the ileocecal valve and was placed a gastrostomy tube by laparotomy. Histologic examination showed full thickness ischemia of the bowel wall. Low molecular weight heparin was initiated on postoperative day (POD) 2 and was switched to oral warfarin on POD 13. At the POD 10, atelactasis developed which was treated successfully with non-invasive ventilation.

Postoperatively, she received parenteral nutrition (PN) for 45 days. Enteral nutrition (EN) with polymeric formula through gastrostomy tube was initiated on POD 10 and gradually increased as the PN diminished. When she was receiving $75 \%$ of her total caloric requirements through EN, PN was discontinued. She was able to eat meals with high protein, low carbothydrate and fat on POD 30. EN via gastrostomy was stopped on POD 63. She was discharged with a free diet on POD 60. On her outpatient clinic visit four months after surgery, her growth and weight gain was normal with a free diet, she suffered no thrombotic events under anticoagulant therapy.

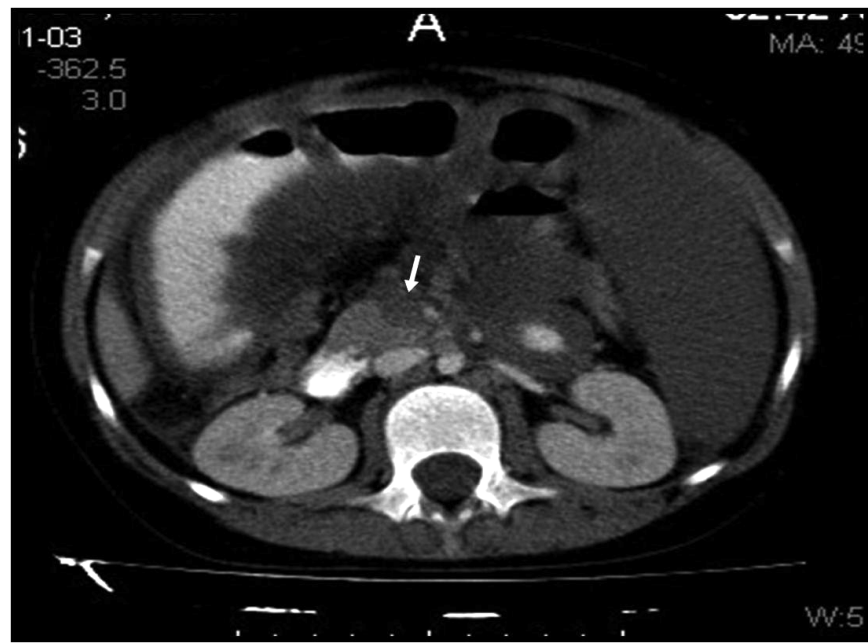

Figure 1: Contrast-enhanced axial CT images of the upper abdomen showing portal vein thrombosis (arrows) extending to the confluence (arrow) and splenic infarct.

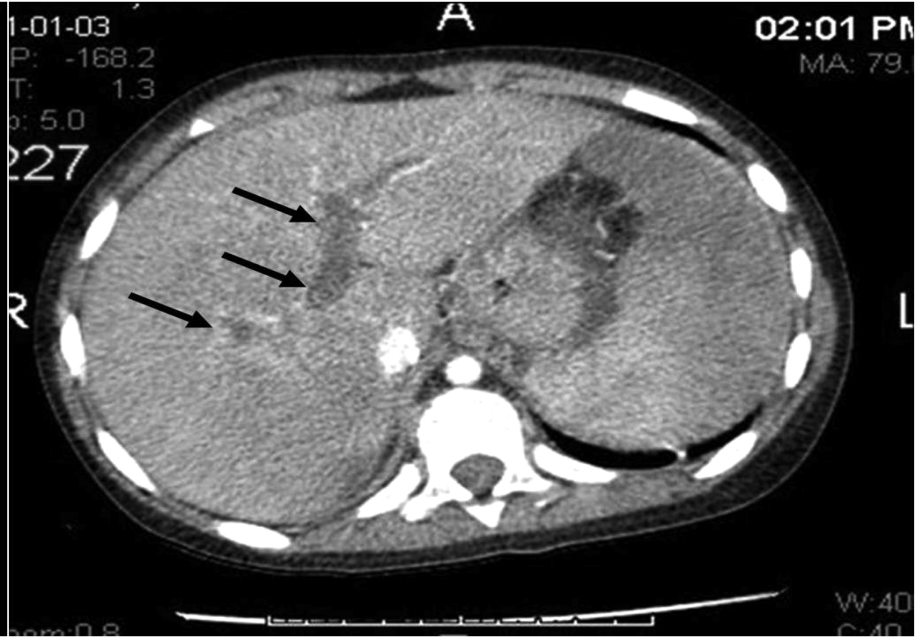

Figure 2: Contrast-enhanced axial CT images of the upper abdomen showing extensive thrombosis of the superior mesenteric vein.

\section{DISCUSSION}

Mesenteric vein thrombosis is mostly seen in patients with hypercoaguable states, pancreatic or biliary malignancies, or intra-abdominal infections, and in blunt abdominal trauma. An inherited thrombotic disorder is found in $25 \%$ of cases [2]. Previous history of thromboembolism or family history is usually present and it is important to obtain a detailed past medical and family history as in our case. Protein
S deficiency is an autosomaldominant inherited disorder of coagulation. Three subtypes of PSD are recognized. Whereas types I and III (also known as type IIa) are quantitative defects, type II is a qualitative defect (also known as type IIb) [4]. Although PSD is uncommon in the general population, it is found in approximately $1-13 \%$ of patients with venous thromboembolism [5]. Frequently these thrombotic events are accompanied by some precipitating factors such as surgery, trauma and infection. However, in children MVT is a rare manifestation of this inherited disorder, and to our knowledge, our patient is the second pediatric clinical report. Mesenteric vein thrombosis was probably precipitated by dehydration in our case.

Intestinal necrosis caused by MVT is the most serious and often fatal complication in childhood $[1,6]$. Patients with intestinal necrosis present with acute abdominal pain 
and urgent diagnosis and intervention are required. Nausea, anorexia, vomiting, and diarrhea are also common. Melena or haematochezia occurs in $15 \%$ of cases, and occult blood is detected in at least half of patients [7]. Our patient who had intestinal infarction presented with vomiting, hematemesis and acute abdomen.

Laboratory blood tests are not helpful in the diagnosis of MVT. The presence of increased serum lactate levels and metabolic acidosis may serve to identify patients with established bowel infarction, but this is a late finding [8]. There is no radiographic gold standard for the diagnosis of

\section{REFERENCES}

1. Oguzkurt P, Senocak ME, Ciftci AO, et al. Mesenteric vascular occlusion resulting in intestinal necrosis in children. J Pediatr Surg 2000; 35: 1161-4.

2. Kumar S, MG Sarr, PS Kamath. Mesenteric venous thrombosis. N Engl J Med 2001; 345: 1683-8.

3. Hayakawa T, Morikomo A, Nozaki Y, et al. Mesenteric venous thrombosis in a child with type 2 protein $\mathrm{S}$ deficiency. J Pediatr Hematol Oncol 2011; 33: 141-3.
MVT, but contrast enhanced CT and mesenteric angiography are the most useful diagnostic modalities [9]. Abdominal CT led to prompt diagnosis of small bowel necrosis in our patient.

Treatment of MVT usually involves a combination of anticoagulation, thrombolysis and surgery. Immediate anticoagulation with heparin early in the course of the disease should be initiated as in our case. The use of thrombolytic agents is limited by the risk of hemorrhage and the low rate of success in cases in which the diagnosis has been delayed [2]. Surgery is indicated in cases with bowel infarction or peritonitis as in

4. ten Kate, M.K. and J. van der Meer, Protein S deficiency: a clinical perspective. Haemophilia, 2008. 14: 12228.

5. Seligsohn U, and Lubetsky A. Genetic susceptibility to venous thrombosis. N Engl J Med 2001; 344: 1222-31.

6. Amitrano L, Guardascione MA, Scaglione $\mathrm{M}$, et al. Prognostic factors in noncirrhotic patients with splanchnic vein thromboses. Am J Gastroenterol 2007; 102: $2464-70$. our patient. In patients with thromboembolism, particularly affecting the cerebral or splanchnic circulation (as in our case), use of long-term anticoagulant therapy is warranted.

In conclusion, MVT is associated with a high rate of morbidity and mortality. Successful treatment of MVT relies on prompt diagnosis. Early diagnosis requires a high index of suspicion. In the evaluation of acute abdomen, mesenteric ischemia must be kept in mind for children and when diagnosed, possibility of an hypercoagulation disorder should be considered.

7. Harward TR, Green D, Bergan JJ, et al Mesenteric venous thrombosis. J Vasc Surg 1989; 9: 328-33.

8. Hotoleanu C, Andercou O, and Andercou A. Mesenteric venous thrombosis: clinical and therapeutical approach. Int Angiol 2008; 27: 462-5.

9. Kim AY, and Ha HK. Evaluation of suspected mesenteric ischemia: efficacy of radiologic studies. Radiol Clin North Am 2003; 41: 327-42. 
